\title{
Possibilities of safe yield increase in the Wydrzany well field (Uznam Island, Poland) by surface water from a drainage system
}

\author{
Ryszard Hoc ${ }^{1 *}$, Andrzej Sadurski², Zenon Wiśniowski ${ }^{1}$ \\ ${ }^{1}$ Pomeranian Branch of Polish Geological Institute NRI, Wieniawskiego 20, 71-130 Szczecin, Poland \\ ${ }^{2}$ Faculty of Earth Sciences, Nicolaus Copernicus University, Lwowska 1, 87-100 Toruń, Poland \\ *corresponding author, e-mail: rhoc@pgi.gov.pl
}

\begin{abstract}
In parallel with intensified development of the Polish part of Uznam Island, there is an increase in the demand for drinking water in this area. This island ranks among areas with low water resources, which at the present time are allocated. In order to create the prospect of increased groundwater resources, a concept has been developed that allows for the recovery of part of the freshwater from drainage systems which discharge into the waters of Szczecin Lagoon or the River Świna. The present article discusses the secondary use of water from drainage systems for supply of the Wydrzany resource area. The notion of using water from the White Bridge pumping station was considered the most promising. The catchment area of the polder is 880 ha, 280 ha of which are located on Polish territory. The White Bridge pumping station transfers water from the polder, which it leads to the Peat Channel which, in turn, drains water gravitationally into Szczecin Lagoon. Here, results of simulations aimed at the use of drainage water to improve upon groundwater resources in the "Wydrzany" intake are discussed. On the basis of these simulations of artificial water supply to the intake, an increase of available resources by up to 50 per cent may be expected.
\end{abstract}

Key words: water supply, Świnoujście, groundwater balance, groundwater flow modelling, groundwater intake

\section{Characteristics of the study area}

\subsection{Geological structure}

Wells and research boreholes drilled on the territory of Uznam Island, as well as series of geophysical probing, enable to present the geological structure of the area with a high degree of accuracy (Matkowska, 1997; Gurwin \& Ruszkiewicz, 2009; Firlit et al., 2012). The underlying Quaternary sediments consist of Cretaceous marlstones, the top of which varies and is located at elevations between -30 and $-80.0 \mathrm{~m}$ a.s.l. On top of the Cretaceous sedimentary rocks follows a continuous layer of glacial clays, which have been classified as belonging to the El- sterian and Warthanian glaciations; their thickness ranges from 5 to 30 metres. These formations are covered by variously grained sands and gravels with cobbles of the Vistulian glaciation occurring in the entire area described above. In the upper part of the section, sediments of the last glaciation are represented by marginal and fluvioglacial deposits. On top of these, Holocene fluviatile units can be found, mainly sands and, locally, sludge and marine sands, the thickness of which ranges on average from 10 to 14 metres (Fig. 1). This part of the section is markedly diverse lithologically. The Holocene formations can be divided into two parts: a lower one, which formed prior to the Lithorine transgression and an upper one comprising Lith- 


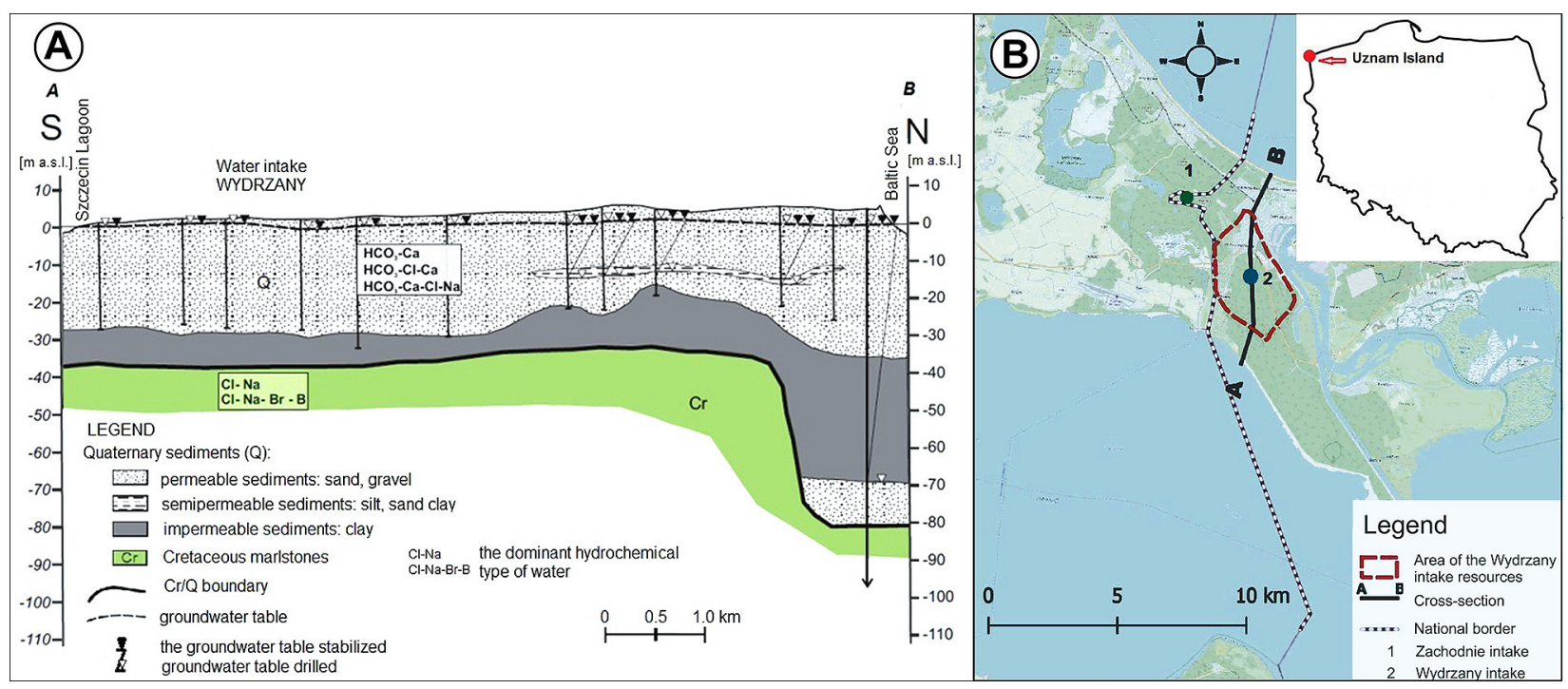

Fig. 1. Study area: A - Hydrogeological cross-section; B - Localization of the "Wydrzany" intake

orine and post-Lithorine strata. The pre-Lithorine deposits constitute a series of sandy sediments covered by peats, silts or loams. The series is discrete and its thickness varies from approximately 2.5 to 6 metres in the case of silts. Above the lower Holocene formations can be found the Lithorine series, consisting of variously grained sands and, locally, of gravel, which change upwards into (aeolian) dune sands. Their thickness attains a maximum thickness of 25 metres, but predominantly ranges between 8 and 14 metres.

\subsection{Hydrogeological conditions}

The current hydrogeological picture indicates the occurrence of two aquifers in the area of the Polish sandbar and deltaic part of Uznam Island: Mesozoic (Cretaceous) and Quaternary (Matkowska et al., 1970; Buckow et al., 2006; Gurwin \& Ruszkiewicz, 2009; Firlit et al., 2012; Krawiec, 2013). The Cretaceous aquifer on Uznam Island contains water that ranges from freshwater at the top of the aquifer to highly mineralised water in deeper-lying parts of the Mesozoic layers, which is used for curative purposes at the Świnoujście health resort (Firlit et al., 2012; Wiśniowski et al., 2014).

The main usable aquifer on Uznam Island, which comprises freshwater, is of Pleistocene and Holocene age. This aquifer is divided into two layers separated locally by a level of silts, sands mixed with clay or silty sands.

The Pleistocene part of the aquifer is recharged mainly by means of direct infiltration of precipitation and locally by means of penetration through loams, sandy silts and silty sands. The recharge conditions are very favourable since permeable formations cover 80 per cent of the area. The majority of permeable formations consists of dune sands, which are highly water permeable. The hydrological parameters for this usable aquifer have been documented, as follows: transmissivity $T_{a v g}=1200$ $\mathrm{m}^{2} / \mathrm{d}$, average hydraulic conductivity $k_{\text {avg }}=10.1$ $\mathrm{m} / \mathrm{d}$ as well as aquifer thickness in the range of 6.0 to 30.0 metres. This aquifer provides almost exclusively freshwater. Its recharge occurs by means of direct infiltration of meteoric water or via infiltration and lateral supply from surface waters. The thickness of the Holocene part of the aquifer ranges from 6 to 18 metres. This aquifer is characterised as an unconfined aquifer, the thickness of the unsaturated zone being dependent of terrain relief. The hydraulic conductivity of the Holocene aquifer amounts to $k_{\text {avg }}=1.0 \mathrm{~m} / \mathrm{h}$, whereas transmissivity reaches $T_{a v g}=1.4 \mathrm{~m}^{2} / \mathrm{h}$.

Due to the location of the town of Świnoujście, there are favourable conditions for maritime and tourist economic development in this area. However, this development is linked to an increased demand for water, which is supplied from two groundwater intakes, "Zachodnie" and "Wydrzany". The present paper discusses the results of studies aimed at an increase of safe yields at the "Wydrzany" groundwater intake. The water intake has approved a safe yield of $Q=300 \mathrm{~m}^{3} / \mathrm{h}$, but some authors of groundwater flow models demand reduction of exploitation even down to $200 \mathrm{~m}^{3} / \mathrm{h}$ (Gurwin \& Ruszkiewicz, 2009; Firlit et al., 2012; Krawiec, 2013). The area in question undergoes salinisation of groundwater due to sea water ingression from the Baltic Sea or the ascension of brines from Mesozoic strata at the bottom of the Quaternary aquifer 
as a result of the "Wydrzany" groundwater intake exploitation. An important factor that limits and delays salinisation of the aquifer in the Wydrzany area is the method of operation of individual wells and limited exploitation of water intake for longer periods of time, as well as additional infiltration of drainage surface waters. High demands for water from the supply to the town of Świnoujście occur during the summer season when it is twice larger than the annual average.

\subsection{Water catchment areas in the Polish part of Uznam Island}

The division into catchments of surface water and groundwater has been adopted on the basis of the inventory carried out by the INBUD company (Skuza \& Woźniak, 2015). It has allowed the assignment of particular parts of the catchment to the main collecting pipes that discharge meteoric waters. These areas have been designated both on account of the current condition of the rainwater sewage system and its projected changes. The designated catchments are delineated in Figure 2.

The inventory of rainwater sewage system carried out by the INBUD company has enabled the separation of catchment assigned to main collecting pipes discharging meteoric waters to determine the amount of water that can be fed to the planned infiltration basins, in order to estimate the amount of water collected in the rainwater drainage system.

\subsection{Reduction of infiltration through surface sediments in the area of Uznam Island}

The degree of surface sealing within the town limits has a significant impact on the calculation of values of recharging infiltrational water. Sealing, which reduces infiltration, has been designated on the basis of analyses of a high-resolution orthophotomaps, which enables a precise definition of the range of buildings and urbanised surface areas within particular survey plots. Development plans were also taken into account, especially in the northern part of the study area.

Areas with seals, i.e., reduction of effective infiltration between 5 and 100 per cent, have been marked. This means that the area marked as 5 per cent represents sealing between 5 and 10 per cent, that marked as 10 per cent representing sealing between 10 and 20 per cent and so on. Areas with sealing levels of 80 per cent for the current state of 90 per cent for the programmed state, denote sealing between 80 (90) and 100 per cent. Areas that lack

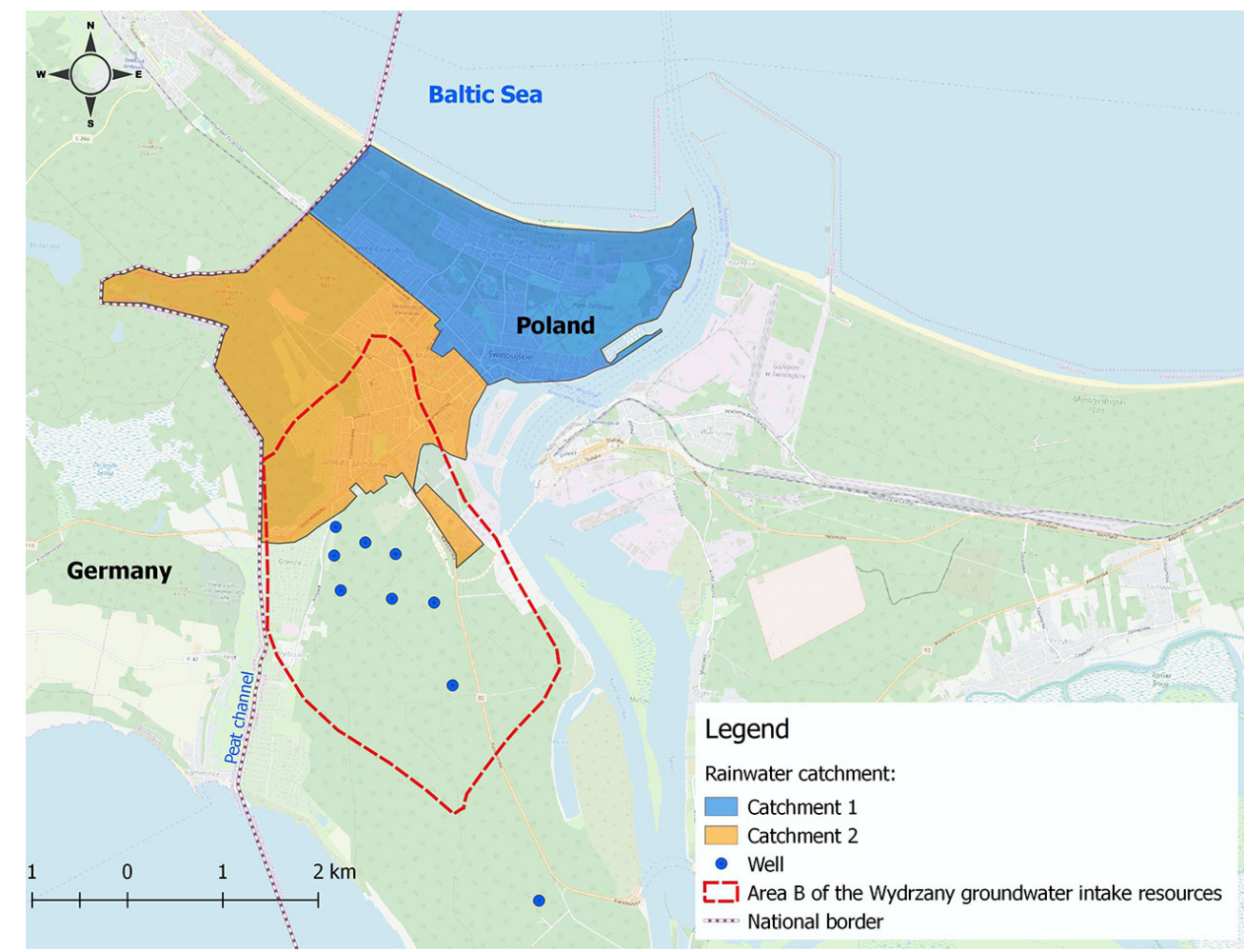

Fig. 2. Catchment area of meteoric waters in the Polish part of Uznam Island 


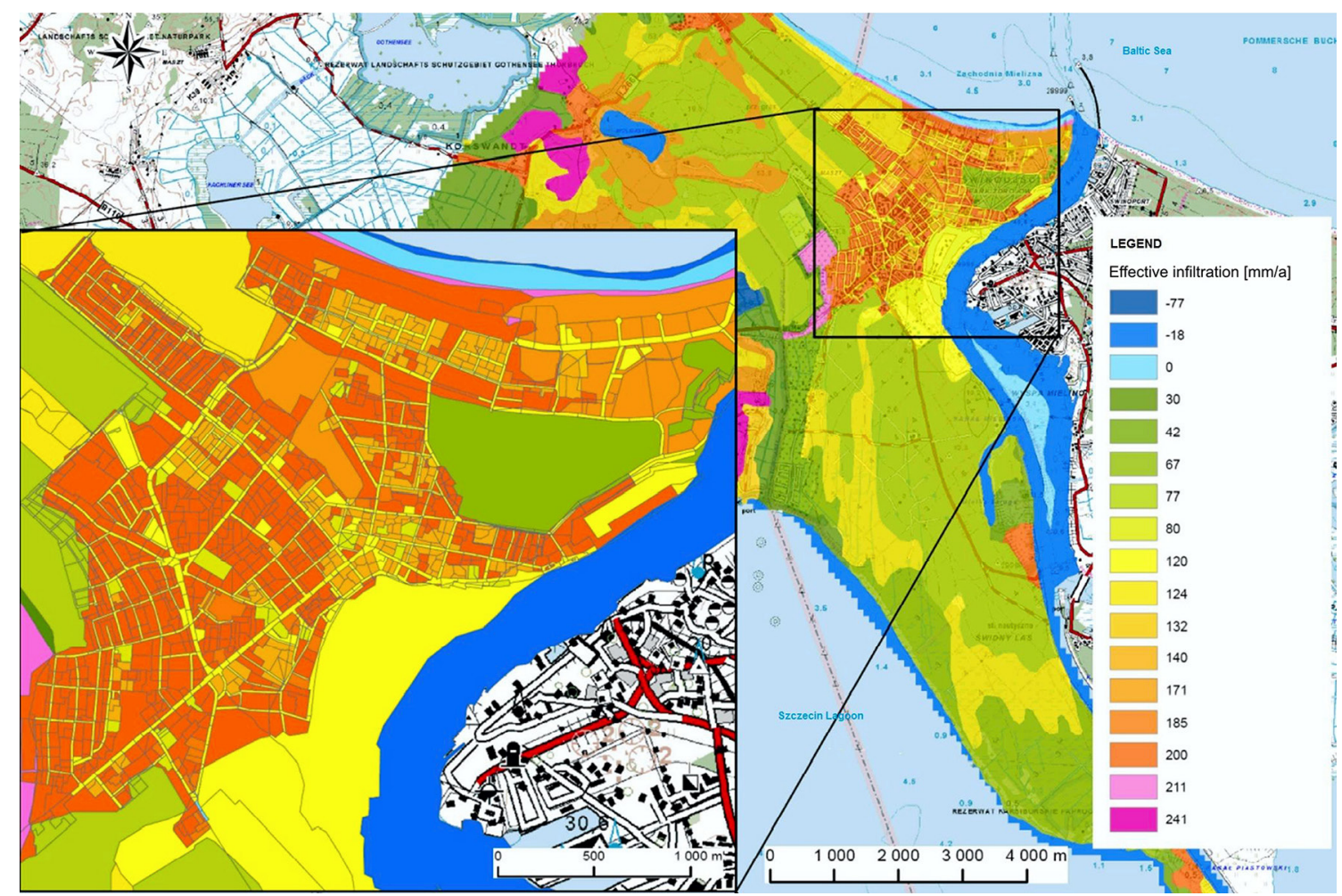

Fig. 3. Effective water permeability of subsurface sediments for the programmed state of land use and meteoric water drainage in a wet year

artificial land cover ( 0 per cent sealing) and those whose degree of sealing represents $<5$ per cent, are marked as remaining areas outside of colour polygons (Fig. 3).

\section{Research methods}

To carry out the analysis of water recovery from drainage, Visual MODFLOW software v.4.2, in which the hydrogeological conditions of Uznam Island were modelled, has been applied. The borders of the model were based on surface water courses - the River Świna as well as the shoreline of the Baltic Sea and Szczecin Lagoon. The hydrogeological parameters and other information ascribed to particular computational blocks constituted the contents of the tables of input data, needed to perform simulations. For the development of the mathematical model computer maps of elevation, top and bottom of geological levels, including ordinates of the groundwater table in the case of unconfined aquifers, have been created. In terms of aquifer filtration properties, the adopted values are based on the outcome of field tests (pumping tests), as well as of laboratory tests, while for the II model aquifer, data were taken from the literature (Matkowska et al., 1970; Buckow et al., 2006; Gurwin \& Ruszkiewicz,
2009; Firlit et al., 2012; Wiśniowski et al., 2014). The existing groundwater circulation system of the area modelled, as already mentioned, was brought in the conceptual model to a three-layer system, which was applied for further modelling tests. In specific calculation blocks of the model, the ordinates of groundwater table were calculated based on measurement data from drilled wells and piezometers as well as surface water level. The model uses boundary conditions as follows:

- the boundary condition of the first type was applied to the boundary of two main surface water bodies: the Baltic Sea and Szczecin Lagoon. The same boundary condition was applied along the River Świna;

- the boundary condition of the second type was applied in order to simulate the top-up of precipitation infiltration to the first aquifer and groundwater intakes using aquifers of specified capacity;

- the boundary condition of the third type was applied in the simulation of Uznam Island canals and lakes.

Verification of the model was carried out by analysing previously documented changes in the position of the hydrodynamic field, as well as by comparing results of the water balance with the neighbouring aquifer systems, in this particular case 
from the German part of Uznam Island. To verify the model, measurements of the water table from 29 wells and piezometers were used, which yielded a correlation coefficient of the model of 0.98 . The difference between the calculated and measured groundwater table amounted to 0.006 to $0.56 \mathrm{~m}$.

\section{Effective infiltration in the area modelled}

The effective permeability for the resource area of the "Wydrzany" groundwater intake of the town of Świnoujście has been calculated by means of the Bagrov \& Glugla method (see Buckow et al., 2006), which takes into account the factor of land use. On the basis of the CORINE Land Cover Map, effective permeability has been calculated, distinguishing ten types of land use: coniferous forest, deciduous and mixed forest, arable land, grassland, dry grassland, countryside (unsewered villages), municipality (sewage network), marsh and surface water reservoirs. As a matter of fact, the "sealing" of soils can be defined as the separation of the humusphere from the atmosphere.

The transition from "sealed" land, through partially "sealed" land, to completely "unsealed" land (characterised by natural water permeability) is smooth. Generally, the higher the level of sealing, the lower the degree of evaporation, and the greater surface runoff or direct outflow. The rise in the direct outflow participation is considerably higher than the decrease in evaporation; therefore, the sustainability of groundwater resources is reduced along with an increase in the level of surface sealing due to urbanisation.

\section{Simulations of groundwater flows resulting from artificial groundwater recharge in the resource area of "Wydrzany" intake}

First and foremost, the management of water discharged into the drainage ditches and infiltration wells located on the premises of allotments, coming from the allotment catchment 1 area were analysed. This was estimated by means of the notion that this catchment area can transfer up to $166 \mathrm{~m}^{3} / \mathrm{h}$ of water in a wet year. However, the increase in groundwater resources in the area of the "Wydrzany" groundwater intake would be about $50 \mathrm{~m}^{3} / \mathrm{d}$. This is disproportionately low in comparison to the efforts needed to allow the discharge of water from this area into the resource area of the "Wydrzany" well field. Then, simulations were carried out in relation to rainwater drainage from the urban area. It was found that changes in water discharge from urban areas do not cause a significant increase in the water table in the limit of $\pm \Delta H=0.1 \mathrm{~m}$ in an average hydrological year; moreover, there is significant variation in water quality in this area. Consequently, it was stated that rain water discharge from the urban area would not increase groundwater resources considerably, especially when this might be contaminated by pollutants from such areas.

Finally, a new water management concept was adopted, according to which the water is led into a peat channel, through which a large amount of freshwater is discharged from the drainage ditches to Szczecin Lagoon. However, this surface water could be used to increase and rebuild groundwater resources in the area of the "Wydrzany" groundwater intake. The possibility of using water from the White Bridge pumping station can be accepted as the most promising (Wiśniowski \& Hoc, 2017). This pumping station operates a drainage polder to the north of Grunwaldzka Street. The area of the polder catchment amounts to $880 \mathrm{ha}$, approximately 280 ha of which are located in Poland. The White Bridge pumping station transfers water from the polder to the Peat Channel, which, in turn, drains it into Szczecin Lagoon gravitionally, which is not protected against the inflow of salt water from that lagoon.

The water collected on the drainage polders on the Polish and German sides is fresh, with low concentrations of chloride ions. The parameter that can significantly reduce the quality of these waters is the high dark colour associated with high contents of organic matter. During water seepage into the aquifer, the chemical composition of the water will change, which will cause water quality in the usable aquifer not to differ from that of waters currently in use, with the exception of chlorides, the concentration of which will decrease. The detailed characteristics of the White Bridge pumping station's performance are presented below.

In 2013 the total amount of pumped water exceeded $28,00,000 \mathrm{~m}^{3}$, which gives a mean daily value of approximately $7,775 \mathrm{~m}^{3} / \mathrm{d}$ for that year. It was assumed that, in order to maintain the necessary flows in the Peat Channel, it would be feasible to use merely 50 per cent of the discharged water, namely around $3,300 \mathrm{~m}^{3} / \mathrm{d}$ as an annual average. This value was adopted in the further procedure, particularly in simulations concerning calculations of artificial groundwater recharge with water from the White 


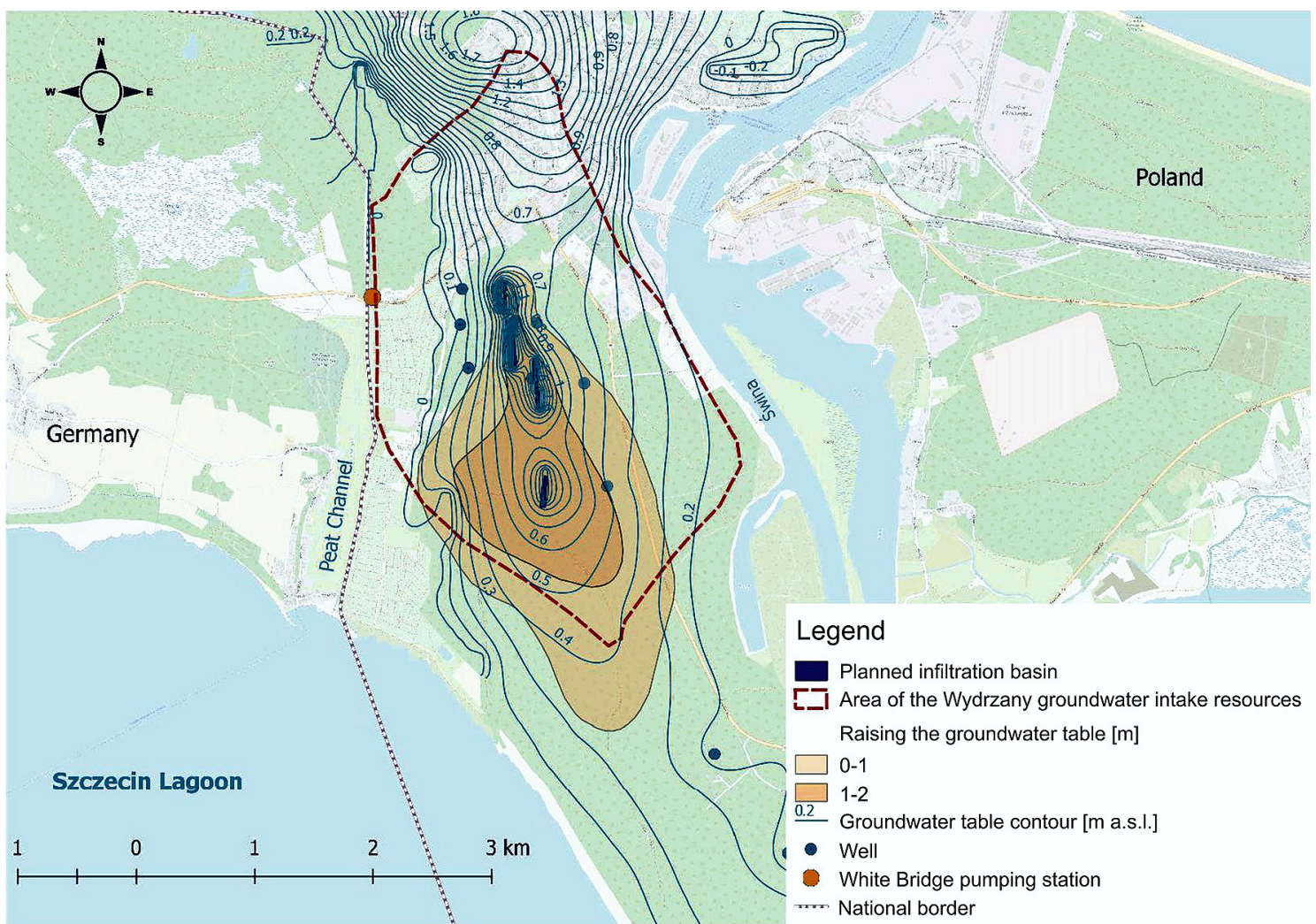

Fig. 4. The location of planned infiltration basins in the "Wydrzany" groundwater intake area

Bridge pumping station. On the basis of model simulations, it was concluded that the most favourable conditions had been reached owing to the assumption that surface water after pretreatment should be recharged by means of four infiltration basins located in the northern part of the resource area of the "Wydrzany" groundwater intake. The basins were designed in the inter-dune depressions, located in both northerly and southerly directions. Their idea of the concept solution has been marked in Figure 4.

The infiltration basins could cover a total area of $34,470 \mathrm{~m}^{2}$. It has been planned to maintain the water fill of these basins at a level of $0.5 \mathrm{~m}$. The maintenance of specified elevation will be possible due to a system of valves, as well as water flows by means of drainage ditches among particular basins. Before

Table 1. Groundwater balance in the resource area of the "Wydrzany" groundwater intake

\begin{tabular}{|c|c|c|c|c|c|c|c|c|}
\hline \multirow{3}{*}{$\begin{array}{l}\text { Components of the } \\
\text { balance }\end{array}$} & \multicolumn{4}{|c|}{ Resource area B - with artificial supply $3300 \mathrm{~m}^{3} / \mathrm{d}$} & \multicolumn{4}{|c|}{ Resource area B - without artificial supply } \\
\hline & \multicolumn{2}{|c|}{ I part of the aquifer } & \multicolumn{2}{|c|}{ II part of the aquifer } & \multicolumn{2}{|c|}{ I part of the aquifer } & \multicolumn{2}{|c|}{ II part of the aquifer } \\
\hline & inflow & outflow & inflow & outflow & inflow & outflow & inflow & outflow \\
\hline Effective infiltration & 2501 & & & & 2519 & & & \\
\hline $\begin{array}{l}\text { Inflow from surface } \\
\text { waters }\end{array}$ & 39 & & & & 30 & & & \\
\hline $\begin{array}{l}\text { Infiltration from } \\
\text { basins }\end{array}$ & 3300 & & & & & & & \\
\hline $\begin{array}{l}\text { Side inflow to the } \\
\text { water field - area B }\end{array}$ & 332 & & 206 & & 438 & & 538 & \\
\hline $\begin{array}{l}\text { Flows between } \\
\text { layers I and II }\end{array}$ & 731 & 4871 & 4871 & 731 & 31 & 2630 & 2630 & 31 \\
\hline Side runoff & & 449 & & 1515 & & 137 & & 305 \\
\hline $\begin{array}{l}\text { Groundwater ex- } \\
\text { traction }\end{array}$ & & & & 2832 & & & & 2832 \\
\hline $\begin{array}{l}\text { Outflow to surface } \\
\text { waters }\end{array}$ & & 1589 & & & & 252 & & \\
\hline Total & 6904 & 6909 & 5077 & 5078 & 3019 & 3019 & 3168 & 3168 \\
\hline
\end{tabular}


filling the basins, drainage water needs to be put in a pre-treatment station. In the model simulation, which includes water outflow from the White Bridge pumping station into four infiltration basins, the constant head boundary condition was applied for each basin. In this way the water supply to the first aquifer in the quantity of $3,300 \mathrm{~m}^{3} / \mathrm{d}$ was obtained (Table 1 ).

Artificial supply of the first aquifer will cause significant changes in the water balance. Water will infiltrate into the first aquifer through infiltration basins and thus it will participate in the following flows: into the second (lower) part of the aquifer, into surface waters and beyond the boundaries of the resource area of groundwater intake at Wydrzany. For the model simulation of artificial groundwater supply, water balance within the resource area of the water intake at Wydrzany was prepared, in addition to a project elaborated by Wiśniowski \& Hoc (2014). This water balance shows additional supply of the second aquifer at the level of 2,200 $\mathrm{m}^{3} / \mathrm{d}$, which can be used to increase groundwater resources (safe yield) of the "Wydrzany" intake. The water balance presented indicates that, in the case of artificial supply implemented in the manner demonstrated, the inflow from the aquifer will be enhanced by QI-II $=4,800 \mathrm{~m}^{3} / \mathrm{d}$, which will enable an increase of the safe yield (exploited water resources) of the "Wydrzany" water intake by 50 per cent in comparison to the currently approved safe yield.

\section{Conclusions}

One proposition to increase groundwater resources (safe yield) of the "Wydrzany" groundwater intake can be artificial recharge of the aquifer with surface water obtained from the drainage system of the Peat Channel. In contrast to water from urban areas, this is devoid of contamination and will not pose a threat to groundwater quality. On the basis of the performed simulations of artificial recharge of the safe yield (exploited resources) of the "Wydrzany" water intake, it can be improved upon by as much as 50 per cent. At a further stage of the studies on the issue concerning water transfer into the resource area of this groundwater intake, a constant quantitative and qualitative monitoring of the water pumped by the White Bridge pumping station is indispensable. This will enable the confirmation of the correctness of the model calculations concerning quantities of water obtainable from the system of drainage ditches, as well as a detailed specification of the prospective impact of the proposed water transfer on the quality of water extracted from the aquifer at the "Wydrzany" water intake.

\section{References}

Buckow, E., Henning, H., Nowacki, F. \& Serafin, R., 2006. Polsko-Niemiecki projekt przygraniczna gospodarka wodami podziemnymi w zlewni obszaru zaopatrzenia Uznam Wschodni/Świnoujście [Polish-German project of near border area in the water catchment in the Eastern Uznam Island/Świnoujcie town]. HGN Hydrogeologie, Proxima S.A., Neubrandenburg, Wrocław.

Firlit, G., Ruszkiewicz, P., Tyralski, M., Mżyk, S. \& Paterek, A., 2012. Dokumentacja hydrogeologiczna ustalajacej zasoby dyspozycyjne wód podziemnych obszaru bilansowego Międzyodrza, Zalewu Szczecińskiego, wyspy Uznam i zachodniej części wyspy Wolin [Hydrogeological documentation of disposable groundwater resources of balance area of Międzyodrze Region, Szczecin Lagoon, Uznam Island and western part of the Wolin Island]. Proxima S.A., Wrocław.

Gurwin, J. \& Ruszkiewicz, P., 2009. Zastosowanie numerycznego modelu filtracji w ocenie wpływu robót inżynierskich na wody podziemne na przykładzie planowanego tunelu między wyspami Wolin i Uznam [Application of numerical flow model in the assessment of planned engineering works on groundwaters on the example of planned tunnel between Wolin and Uznam Islands]. Bulletin of Polish Geological Institute 436, 141-151.

Krawiec, A., 2013. Pochodzenie anomalii chlorkowych w wodach podziemnych polskiego wybrzeża Bałtyku [Origin of chlorine anomaly in the groundwater of Polish Baltic Coast]. Nicholas Copernicus University, Torun, 144 pp.

Matkowska, Z., 1997. Mapa hydrogeologiczna Polski w skali 1:50 000, arkusz Świnoujście [Hydrogeological Map of Poland, 1:50 000, Świnoujście sheet]. Polish Geological Institute, Warszawa.

Matkowska, Z., Porek, M., Rembocha, L. \& Wdowiak, M., 1970. Geologiczne opracowanie Bramy Świny [Geological description of Świna Gate]. Polish Geological Institute, Warszawa.

Skuza, D. \& Wozniak, Z., 2015. Kompleksowa inwentaryzacja sieci kanalizacji deszczowej dla lewobrzeżnej części miasta Świnoujście wraz z określeniem poszczególnych zlewni, ich rzeczywistych wielkości oraz koncepcja określająca rozwój (modernizację) systemu kanalizacji deszczowej uwzględniający bieżace oraz planowane potrzeby zrównoważonego rozwoju miasta Świnoujście - Etap I i II [Complex register of groundwater sewage system Świnoujście town with delimitation of river catchments area and conception of rainwater drainage system construction, according to the sustainable development of the town - step I and II]. INBUD Project Office, Szczecin.

Wiśniowski, Z. \& Hoc, R., 2014. Wptyw zmian gospodarowania wodami opadowymi na obszarze Świnoujścia w cześci położonej na Wyspie Uznam na stan wód gruntowych $i$ przeptyw wód podziemnych [Impact of meteoric water menagement on the Świnoujście area In Wolin Island on the groundwater head and outflow]. Pomeranian Branch of Polish Geological Institute, Szczecin.

Wiśniowski, Z., Hoc, R. \& Jezierski, P., 2014. Dodatek nr 1 do dokumentacji hydrogeologicznej ustalającej zasoby dys- 
pozycyjne wód podziemnych obszaru bilansowego Międzyodrza, Zalewu Szczecińskiego, wyspy Uznam i zachodniej części wyspy Wolin [Supplement to hydrogeological documentation of disposal groundwater resources of the area of Uznam Island, Gulf of Szczecin and western part of Wolin
Island]. Pommeranian Branch of Polish Geological Institute, Szczecin.

Manuscript received: 28 May 2019

Revision accepted: 23 October 2019 